\title{
Indonesia Local Industry Structure and Firms Productivity in Industrial Area
}

\author{
Rinayanti $^{1^{*}}$, Riatu Mariatul Qibthiyyah ${ }^{2}$
}

1,2Universitas Indonesia, Indonesia

Email: ${ }^{1}$ rinayanti.rahmad@gmail.com, ${ }^{2}$ riatu.mariatul@ui.ac.id

${ }^{*}$ Corresponding author

\section{JEL Classification:}

D24

L52

R10

Received: 30 April 2020

Revised: 27 November 2020

Accepted: 22 December 2020

\begin{abstract}
Using three industry structure indices: specialization, diversification, and competition, we explore how local industry structure may affect firm productivity in the industrial estates. Based on unbalanced panel data of large and medium-sized industrial firms in Indonesia during 2010-2015, our study found that local industry structure influences firm productivity, measured as total factor productivity (TFP). The effect differs between firms outside the industrial estate and firms in the industrial estate. Specialization decreases the productivity of both firms in the industrial estate and outside. Diversification has a positive effect on increasing firm productivity in the industrial estate. As for firms outside the industrial estate, diversification has a negative effect, but the effect is less significant. Meanwhile, local industry competition has a positive and significant effect on firm productivity outside the industrial estate, but the effect is not significant for firms within the industrial estate. Empirically, firms in industrial estates may only benefit from a diversified local industry structure.
\end{abstract}

\section{Keywords:}

local industry structure, industrial estate, firm productivity.

How to Cite:

Rinayanti., \& Qibthiyyah, R. M. (2021). Indonesia Local Industry Structure and Firms Productivity in Industrial Area. Signifikan: Jurnal Ilmu Ekonomi, 10(1), 93 - 112. doi: http://doi.org/10.15408/sjie.v10i1.17197. 


\section{Introduction}

Indonesia Government Regulation Number 142 of 2015 and Law Number 3 of 2014 define Industrial Estates as areas where industrial activities are concentrated, given that it is supported by facilities and infrastructure developed and managed by Industrial Estate Firms. Industrial estates are natural and historically have been social and territorial entities characterized by the active presence of both communities and firms Becattini (1990). In industrial estates, communities and firms tend to be close. The benefit of industrial estates is its agglomeration effect, which benefits firms from locating close to each other compared to being separated (Glaeser, 2010).

The industrial estate area is one of the policy options for forming a spatial concentration of the manufacturing industry sector. The industrial sector's spatial concentration will attract other economic activities resulting in agglomeration (Cainelli, 2008). Several previous studies have focused on the positive effects of spatial agglomeration on productivity. The most traditional one is the study of Marshallian industrial districts. An analysis of Marshallian thought was carried out, including by Gordon \& McCann (2000), Boschma \& Lambooy (2002), Iammarino \& McCann (2006), Boschma \& Ter Wal (2007). From these studies, industrial estates gained wide fame as a type of industrial organization, where long-term informal relationships between firms produced Marshall agglomeration economies and externalities that replaced the internal economies of scale in each firm (Cainelli, 2008).

The industrial estate area, which is the center of industrial activity, will provide economic benefits or positive agglomeration externalities to the firms within it. ${ }^{1}$ With spatial closeness, firms and workers in specific industries located close to one another, such as in industrial areas, can gain an abundance of knowledge from the same or different technologies, access the combined labor market and skilled workers, and benefit from sharing input items. All of this can increase firm productivity (Gill \& Goh, 2010). However, the benefits obtained can be dynamic and depend on the local industry's structure.

The structure of local industries in the agglomeration area can affect productivity through three types of externalities. The first is specialization externalities or localization economies, externalities that occur from firms with the same industry type. Marshall, Arrow, and Romer developed the concept of the externality of this specialization and in a dynamic context, known as Marshall-Arrow-Romer (MAR) externality (Glaeser et al., 1992). Second, namely diversification externalities or urbanization economies, externalities from the gathering of firms with diverse industrial sectors, allows sharing of ideas and

\footnotetext{
${ }^{1}$ Fan and Scott (2003) have summarized the positive externalities of agglomeration divided the types of externalities into five main problems, namely: grouping firms at close distances can reduce transaction costs incurred per unit distance; the dense local labor market is a better opportunity for job seekers and job openings; transactional relationships also involve the flow of business information or an abundance of specific knowledge; the grouping of various producers is beneficial in encouraging the formation of alliances and profitable business organizations to increase local competitiveness, and the creation of public goods can achieve significant economies of scale due to the use of infrastructure that is spread across many individual firms in one location.
} 
experiments between different economic activities. This second externality was developed by Jacobs and is known as Jacobs externality (Glaeser et al., 1992). The third type of externality is competition, which Porter developed to be known as Porter's externality. According to Porter, local competition plays an essential role in the firm's progress, and the primary source of pressure on the firm is to create innovative products and adopt new technologies (Glaeser et al., 1992).

According to the concept of MAR externality (specialization), spatial areas with sectors that are concentrated in certain types of industries will attract and encourage the occurrence of a large pool of labor (labor pooling), including workers who have been trained and have particular expertise in specific industrial fields. Besides, the concentration of economic activity in specific sectors will trigger the entry of specialist intermediate input goods suppliers to the area, which in turn will reduce transaction costs between suppliers and firms, as well as firms, get cheaper input goods prices due to the economies of production from suppliers that serve large-scale specialized input items. Finally, firms that are agglomerated and involved in the same sector benefit from the knowledge spillover because the geographical closeness between actors will encourage the emergence of new ideas or improvements related to products, technologies, and management of the firm's organization (Van Oort, 2015). All of these things will ultimately increase the productivity of the firms involved.

Meanwhile, according to the Jacobs externality concept (diversification), the essential source of knowledge comes from the external sector, namely, the sector outside the firm operates. In contrast to Marshall, Jacobs stressed that diverse local industries would trigger an overflow of knowledge and ultimately increase the emergence of ideas and innovations (Galliano et al., 2015). A more diverse industrial structure at close range encourages opportunities to emulate, share and recombine ideas and practices across industries (Beaudry \& Schiffauerova, 2009). Complementary knowledge exchanges will encourage research and experimentation, and a more diverse economy will contribute to this complementary knowledge base. The exchange of knowledge between industries will encourage new ideas, product innovation, technological improvement, or firm organizations' improvement, which will increase firm productivity.

Like MAR, Porter argues that an abundance of knowledge in a geographically specialized and geographically concentrated industry will trigger growth. However, Porter also stressed that local competition, which is the opposite of a monopoly, will spur the search for and rapid adoption of innovations. Porter's externalities will occur maximally in areas with industries that are geographically and competitively specialized (Glaeser et al., 1992). Like Porter, Jacobs also believes that local competition will accelerate technology adoption (Glaeser et al., 1992).

Studies on the effects of agglomeration in local industry structure have been carried out in many countries. The positive, negative, and insignificant effects of externalities of specialization (MAR), diversification (Jacobs), and competition (Porter) are found in various studies (Beaudry \& Schiffauerova, 2009; Knoben et al., 2016; Rigby \& Brown, 
2015). Likewise with empirical studies in Indonesia, including by Kuncoro (2009), Widodo et al. (2014), Wardani \& Yudhistira (2020), and Khoirunurrofik (2018).

Research by Malmberg et al. (2000), Antonietti \& Cainelli (2011), Li et al. (2012), Badr et al. (2019), Cheng \& Jin (2020) concluded that both specialization and diversification have a positive impact on firm performance. Meanwhile, research by Widodo et al. (2014), Galliano et al. (2015), Cieślik et al. (2017), Wardani \& Yudhistira (2020) concluded that only specialization has a positive effect, while diversification harms firm performance. Batisse (2002) found that specialization harms regional growth, while diversification has a positive impact. Not only that, Fafchamps \& El Hamine (2017), using geographic zones of agglomeration at the sub-city, city, and provincial levels, find that the only specialization has a positive impact on firm productivity, while the impact of diversification is still doubtful. The research results by Fafchamps \& El Hamine (2017) are in line with Wixe (2015) study, which found that specialization had a positive effect on firm productivity, while there was no substantial evidence for Jacobs' externality.

The positive effect of competition was found in Badr et al. (2019), Khoirunurrofik (2018), Wixe (2015), and Cielik et al. (2017). Meanwhile, Fafchamps \& El Hamine (2017) research results and Van der Panne (2004) found the competition's negative effect. Some studies only analyze the effect of MAR and Jacobs externalities and do not analyze the externalities of competition, among them by Galliano et al. (2015), Kuncoro (2009), and Malmberg et al. (2000).

In Indonesia, specific studies portraying the character of firms in industrial areas are still limited. Existing studies so far were only comparing firm performance inside and outside the region in general and did not capture its local industry structure effect (Aritenang \& Chandramidi, 2020; Sabri et al., 2018; Suharyani \& Mahi, 2018; Winardi et al., 2017). Notable empirical studies in Indonesia on the effect of local industry structure are Wardani \& Yudhistira (2020), Khoirunurrofik (2018), Widodo et al. (2014), and Kuncoro (2009). However, these studies have not incorporated regional specific characteristics, namely the firm's location inside or outside industrial estates. Unlike previous studies, this paper will examine the effect of local industry structure on firm productivity by differentiating between firms located inside and outside industrial estates. We want to know which one will increase firm productivity, located inside or outside the industrial estate, and co-locate firms with similar or diverse industries to boost productivity.

The agglomeration of manufacturing firms in the industrial area supposedly leads to an agglomeration economy. Law Number 3 of 2014 on Industry stated that every industrial business firm, mostly large firms, is required to be located in an industrial area. However, the Law exempted small and medium firms for this requirement, and therefore, these firms may locate either in the industrial area or outside the industrial area. The exemption may be due to perceived low-risk activities from these small and medium firms, for example, referring to the risk of environmental pollution or industries that 
use unique raw materials, and thus their production processes require to be conducted in unique locations. This study examines whether firms agglomeration in the industrial estate (area) will increase firm productivity, measured in total factor productivity (TFP). Does firms with similar or diverse industries located in the same industrial area and or administrative areas (municipality or city) will increase firm productivity. Specifically, this study examines the influence of local industry structures, namely specialization, diversification, and competition, on firm productivity.

Compared with existing literature, our study's novel contribution is examining the influence of local industry structures by differentiating firms' location inside or outside industrial estates, which has never been done before in Indonesia, by focusing more on firms in industrial estates. This is due to the Indonesian government policy to require every new industrial firm to be located in an industrial area (Law 3/2014 on Industry). This study's results are expected to provide input to the government, which industrial structures are profitable for firms in industrial estates, groups of firms on co-location with similar or diverse industries that will increase firm productivity in industrial estates. Our study has also used a novel dataset, referring to a more complete data of firm location, by merging the data in Statistik Industri (SI) with Manufacturing Industry Directories. We identify firm location inside or outside industrial estate by looking at the details on each firm's address because of the large number of missing location data in Statistik Industri.

\section{Methods}

This research uses panel data from the Large and Medium Industrial Statistics (IBS) 2010-2015 from the Central Statistics Agency (BPS). The census is carried out annually on manufacturing firms that have a minimum workforce of 20 people. Variables from IBS statistical data used in this study include firm identity number, provincial code, district code, location inside or outside the industrial area, leading product, capital percentage, total labor, income, value-added, assets, use raw materials, fuel, and electricity.

Specific to data on industrial estates, we identify that in IBS 2010-2015, there are missing values on the status of the firm of whether it is located within the industrial estate or outside the industrial estate of 75,511 observations, and therefore we merge the IBS data with IBS Directory, and database of Industrial Estate Tenants Directory to verify and to fill the missing as well as incorrect data on the location of the firm.

Overall, the data used in the study is unbalanced panel data with the number of observations used as a sample of 91,662 observations from 2010-2015. This data includes 21,127 firms (with not all firms appearing every year), 24 types of industrial sectors from ISIC-10 to ISIC-33, and 328 Regencies/Cities. 
Regarding the literature review and the objectives of this study, the estimation model specification is as follows:

$$
\begin{aligned}
& \ln \left(\text { TFP }_{i k j t}\right)=\alpha_{0}+\alpha_{1} z_{-} L Q_{k j t}+\alpha_{2} z_{-} D i v_{k j t}+\alpha_{3} z_{-} \text {Comp }_{k j t}+\gamma_{0} D \_K I+\gamma_{1} D \_K I * \\
& z_{-} L Q_{k j t}+\gamma_{2} D \_K I * z_{-} D i v_{k j t}+\gamma_{3} D \_K I * z_{-} \text {Comp }_{k j t}+ \\
& \beta_{1} \ln \left(\text { Firm_Labor }_{i t}\right)+\beta_{2} \ln \left(\text { KLratio }_{i t}\right)+\beta_{3} D P M A_{i t}+\beta_{4} D G O V_{i t}+\beta_{5} D T_{i k t}+ \\
& \beta_{6} \text { Firm_Share }_{i t}+u_{k}+v_{t}+\varepsilon_{i t}
\end{aligned}
$$

The subscript $\boldsymbol{i}$ refers to firm $i, k$ refers to the industrial sector- $k, j$ denotes the $j^{\text {th }}$ district/city and $t$ states year $t$. The LQ, Div, Comp variables are the primary independent variables that are variable of the specialization, diversification, and competition externalities. $D_{-} K I$ is a dummy variable of the firm located inside or outside the industrial area, which is also our main independent variables. Firm_Labor, KLratio, DPMA, DGOV, DT, Firm_ Share are control variables of firm characteristics, namely the number of employees, the ratio of capital to labor, and capital ownership by foreign firms, ownership of capital by the government, technology, and firm share. $u_{k}$ is a type of industry dummy to capture fixed effects from industry sector groups. $v_{t}$ is a dummy time to capture the fixed effect

\begin{tabular}{|c|c|c|}
\hline Name of Variable & Definition & Unit \\
\hline \multicolumn{3}{|l|}{ Dependent Variable } \\
\hline \multicolumn{3}{|l|}{ Level: Firm } \\
\hline Productivity (TFP) & $\begin{array}{l}\text { Firm productivity measured by Total Factor Productivity } \\
\text { (in natural logarithm), calculated by the Levinsohn- } \\
\text { Petrin method (2003) }\end{array}$ & Index \\
\hline \multicolumn{3}{|l|}{ Independent Variable } \\
\hline \multicolumn{3}{|c|}{ Level: Industry and District /City } \\
\hline Specialization Index $(\boldsymbol{L} \boldsymbol{Q})$ & $\begin{array}{l}\text { Size of specialization that is, Location Quotient (LQ), } \\
\text { shows the concentration of an industrial sector in a } \\
\text { district/city relative to other districts/cities (standardized } \\
\text { index value) }\end{array}$ & Index \\
\hline Diversification Index (Div) & $\begin{array}{l}\text { Size of diversification, showing the diversity faced by } \\
\text { an industry in a particular region (standardized index } \\
\text { value). This study follows the diversification index used } \\
\text { by Khoirunurrofik (2018) and Marrocu, Paci, and Usai } \\
\text { (2013). }\end{array}$ & Index \\
\hline Competition Index (Comp) & $\begin{array}{l}\text { Size of competition, showing competition between } \\
\text { firms in the same sector in a particular region relative to } \\
\text { competition between firms in the same sector nationally } \\
\text { (standardized index value). To measure competition, it } \\
\text { also follows Khoirunurrofik ( } 2018 \text { ) }\end{array}$ & Index \\
\hline \multicolumn{3}{|l|}{ Level: Firm } \\
\hline $\begin{array}{l}\text { Dummy of Industrial } \\
\text { Area }\left(D_{-} K I\right)\end{array}$ & $\begin{array}{l}\text { Firm located within Industrial Estates will be valued } 1 \\
\text { and } 0 \text { if other. }\end{array}$ & 1 and 0 \\
\hline
\end{tabular}
of the observation year. The definition of explanatory variables used in equation (1) and their data sources are summarized in Table 1.

Table 1. Variable Definition and Data Source 


\begin{tabular}{|c|c|c|}
\hline Name of Variable & Definition & Unit \\
\hline $\begin{array}{l}\text { Firm size by the } \\
\text { number of labor employed } \\
\text { (Firm_Labor) }\end{array}$ & $\begin{array}{l}\text { Firm size, measured by the number of workers (in } \\
\text { natural logarithms) }\end{array}$ & person \\
\hline $\begin{array}{l}\text { Capital per worker ratio } \\
\text { (KLratio) }\end{array}$ & $\begin{array}{l}\text { It is measured by the amount of firm capital value divided } \\
\text { by the number of workers (in natural logarithms). }\end{array}$ & rupiah/ person \\
\hline $\begin{array}{l}\text { Dummy foreign ownership } \\
\text { (DPMA) }\end{array}$ & $\begin{array}{l}\text { The dummy status of capital ownership by foreign firms } \\
\text { is worth } 1 \text { if foreign shares ownership is more than } 10 \% \\
\text { and } 0 \text { if others. }\end{array}$ & 0 and 1 \\
\hline $\begin{array}{l}\text { Dummy ownership by the } \\
\text { government (DGOV) }\end{array}$ & $\begin{array}{l}\text { The government's dummy status of firm capital } \\
\text { ownership is worth one if the ownership of firm shares } \\
\text { by the central government or local government is at } \\
\text { least } 50 \% \text { and } 0 \text { if others. }\end{array}$ & 0 and 1 \\
\hline Dummy Technology (DT) & $\begin{array}{l}\text { The firm's technology dummy is based on the UNIDO } \\
\text { classification. Divided into three industry groups, } \\
\text { namely low technology industries (ISIC 10-19, } 25 \text { and } \\
\text { 31), medium technology industries (ISIC 22-24, 32.33), } \\
\text { high-medium technology industries (ISIC 20-21, 26-30) }\end{array}$ & $\begin{array}{l}\text { Categorical dummy } \\
\text { (1 for low } \\
\text { technology, } \\
2 \text { for medium } \\
\text { technology, and } 3 \\
\text { for high-medium } \\
\text { technology) }\end{array}$ \\
\hline $\begin{array}{l}\text { Firm share from market } \\
\text { share (Firm_Share) }\end{array}$ & $\begin{array}{l}\text { Firm size, measured by market share, is the ratio of } \\
\text { firm output to total output in the ISIC } 2 \text {-digit industrial } \\
\text { sector }\end{array}$ & Percent \\
\hline
\end{tabular}

Notes: The data source for the variables used in this table comes from data Statistik Industri (SI) for 2010-2015. Specific for firm location variables $\left(\boldsymbol{D}_{-} \boldsymbol{K I}\right)$, using combined data from the SI and Manufacturing Industry Directories.

There are heterogeneous characteristics among firms. Each firm also has fixed and does not vary between time (time-invariant), for example, firm management factors or endowments owned by the firm. There is also a potential endogeneity problem due to reverse causality between productivity and agglomeration. Agglomeration externalities can improve productivity, but firms may also self-select locating in high productivity areas that affect the local industry structure. Therefore, the panel data estimation method used in this study is the fixed effect model. Estimation with the fixed-effect model is also expected to overcome the endogeneity problem.

\section{Results and Discussion}

The empirical model specification in equation (1) was estimated using large and medium industrial data from 2010 to 2015 . The number of observations used to estimate 91,662 samples consisting of 5,260 observations was sampled from firms in industrial estates, and 86,402 observations were sampled from firms outside the industrial estate. A statistical summary of the variables used for research is shown in Table 2 .

Table 3 is an estimation result using fixed effects that is by controlling firm-specific fixed effects. In addition to controlling the firm's fixed effects, the regressions in columns (1) through column (5) have also controlled industry-specific fixed effects and year-specific fixed effects. Column regression (1) displays regression only for the primary study variable 
(baseline). The results show that firms average productivity $(\ln T F P)$ in the industrial area is not significantly different from firms outside the industrial area. Besides, the local industry structure's effect on firms in the industrial area does seem to be different from those firms outside the industrial area is only diversification externalities. For firms in the industrial area, diversification has a positive and significant effect, although only at the $10 \%$ level, to increase firm productivity.

Table 2. Summary Statistics

\begin{tabular}{|c|c|c|c|c|c|c|c|c|}
\hline \multicolumn{2}{|l|}{ Variable } & Location & Obs. & Mean & Sd & Min & Max & $\begin{array}{c}\text { Mean } \\
\text { Difference }\end{array}$ \\
\hline \multicolumn{2}{|l|}{ (1) } & (2) & (3) & (4) & (5) & (6) & (7) & (8) \\
\hline \multirow[t]{2}{*}{ Firm Productivity } & \multirow[t]{2}{*}{ (InTFP) } & Non-IE & 86402 & 10.778 & 1.412 & 4.145 & 18.998 & \multirow{2}{*}{$-1.536^{*}$} \\
\hline & & IE & 5260 & 12.315 & 1.334 & 6.585 & 20.192 & \\
\hline \multirow[t]{2}{*}{ Spesialization } & \multirow[t]{2}{*}{$\left(z_{-} L Q\right)$} & Non IE & 86402 & -0.028 & 0.455 & -0.278 & 29.672 & \multirow{2}{*}{$0.037^{*}$} \\
\hline & & IE & 5260 & -0.066 & 0.281 & -0.277 & 2.193 & \\
\hline \multirow[t]{2}{*}{ Diversification } & \multirow[t]{2}{*}{ (z_Div) } & Non IE & 86402 & 0.359 & 1.091 & -1.071 & 3.879 & \multirow{2}{*}{$-1.412^{*}$} \\
\hline & & IE & 5260 & 1.771 & 1.164 & -1.009 & 3.879 & \\
\hline \multirow[t]{2}{*}{ Competition } & \multirow[t]{2}{*}{ (z_Comp) } & Non-IE & 86402 & 0.665 & 2.024 & -0.362 & 37.404 & \multirow{2}{*}{$-0.129^{*}$} \\
\hline & & IE & 5260 & 0.795 & 1.227 & -0.350 & 37.404 & \\
\hline \multirow[t]{2}{*}{ Location Dummy } & \multirow[t]{2}{*}{$\left(D_{-} K I\right)$} & Non-IE & 86402 & 0 & 0 & 0 & 0 & \\
\hline & & IE & 5260 & 1 & 0 & 1 & 1 & \\
\hline \multirow[t]{3}{*}{ Firm Labor } & \multirow{3}{*}{$\begin{array}{l}\text { (InFirm } \\
\text { labor) }\end{array}$} & Non IE & 86402 & 4.085 & 1.153 & 2.996 & 10.958 & \multirow{3}{*}{$-1.009^{*}$} \\
\hline & & & & & & & & \\
\hline & & IE & 5260 & 5.095 & 1.270 & 2.996 & 10.166 & \\
\hline \multirow{2}{*}{$\begin{array}{l}\text { Capital per Worker } \\
\text { Ratio }\end{array}$} & \multirow[t]{2}{*}{ (InKLratio) } & Non-IE & 86402 & 9.972 & 1.769 & -6.632 & 25.110 & \multirow{2}{*}{$-1.291^{*}$} \\
\hline & & IE & 5260 & 11.263 & 2.146 & -0.518 & 26.513 & \\
\hline \multirow{2}{*}{$\begin{array}{l}\text { Dummy Foreign } \\
\text { Ownership }\end{array}$} & \multirow[t]{2}{*}{ (DPMA) } & Non-IE & 86402 & 0.062 & 0.242 & 0 & 1 & \multirow{2}{*}{$-0.531^{*}$} \\
\hline & & IE & 5260 & 0.593 & 0.491 & 0 & 1 & \\
\hline \multirow{2}{*}{$\begin{array}{l}\text { Dummy } \\
\text { Government } \\
\text { Ownership }\end{array}$} & \multirow[t]{2}{*}{ (DGOV) } & Non-IE & 86402 & 0.016 & 0.126 & 0 & 1 & \multirow[b]{2}{*}{$0.009^{*}$} \\
\hline & & IE & 5260 & 0.007 & 0.084 & 0 & 1 & \\
\hline \multirow{2}{*}{$\begin{array}{l}\text { Dummy Technology } \\
\text { Intensity }\end{array}$} & \multirow[t]{2}{*}{$(D T)$} & Non-IE & 86402 & 1.342 & 0.621 & 1 & 3 & \multirow{2}{*}{$-0.662^{*}$} \\
\hline & & IE & 5260 & 2.003 & 0.883 & 1 & 3 & \\
\hline \multirow[t]{2}{*}{ Firm Market Share } & (firm_share) & Non-IE & 86402 & 0.070 & 0.698 & 0.0000 & 70.238 & \\
\hline & & IE & 5260 & 0.332 & 1.358 & 0.0002 & 33.756 & 0.202 \\
\hline
\end{tabular}

Note: ${ }^{*}$ t-test results on the mean difference in all variables indicate significant average differences between firms outside IE (industrial estate) and firms in IE.

Source: Authors processed 
Table 3. Estimation Results: Fixed Effect Estimation

\begin{tabular}{|c|c|c|c|c|c|}
\hline Dependent: & (1) & (2) & (3) & (4) & (5) \\
\hline LnTFP & FE & FE & FE & FE & FE \\
\hline \multirow[t]{2}{*}{ z_LQ } & -0.018 & $-0.034^{* *}$ & $-0.041^{* *}$ & $-0.038^{* *}$ & $-0.037^{* *}$ \\
\hline & $(0.017)$ & $(0.016)$ & $(0.016)$ & (0.016) & $(0.016)$ \\
\hline \multirow[t]{2}{*}{ z_Div } & -0.020 & -0.022 & -0.020 & -0.023 & -0.023 \\
\hline & $(0.014)$ & $(0.014)$ & $(0.015)$ & $(0.014)$ & $(0.014)$ \\
\hline \multirow[t]{2}{*}{ z_Comp } & $0.011^{* * *}$ & $0.010^{* * *}$ & $0.010^{* * *}$ & $0.011^{* * *}$ & $0.012^{* * *}$ \\
\hline & (0.003) & (0.003) & (0.003) & (0.003) & (0.003) \\
\hline \multirow[t]{2}{*}{ D_KI } & -0.798 & -0.946 & -0.827 & -0.806 & -0.855 \\
\hline & $(0.719)$ & (0.706) & (0.704) & $(0.705)$ & $(0.705)$ \\
\hline \multirow[t]{2}{*}{ zLQ_KI } & -0.209 & -0.237 & $-0.273^{*}$ & $-0.272^{*}$ & $-0.249^{*}$ \\
\hline & (0.153) & $(0.150)$ & (0.151) & $(0.150)$ & (0.150) \\
\hline \multirow[t]{2}{*}{ zDiv_KI } & $0.090^{*}$ & 0.072 & $0.089^{*}$ & $0.124^{* * *}$ & $0.108^{* *}$ \\
\hline & $(0.048)$ & $(0.047)$ & $(0.050)$ & $(0.047)$ & $(0.047)$ \\
\hline \multirow[t]{2}{*}{ zComp_KI } & -0.009 & -0.005 & -0.004 & -0.005 & -0.006 \\
\hline & (0.016) & $(0.016)$ & $(0.016)$ & $(0.016)$ & $(0.016)$ \\
\hline \multirow[t]{2}{*}{ InFirm_labor } & & $0.108^{* * *}$ & $0.109^{* * *}$ & $0.109^{* * *}$ & $0.108^{* * *}$ \\
\hline & & (0.009) & (0.009) & (0.009) & (0.009) \\
\hline \multirow[t]{2}{*}{ InKLratio } & & $-0.077^{* * *}$ & $-0.077^{* * *}$ & $-0.077^{* * *}$ & $-0.077^{* * *}$ \\
\hline & & (0.003) & (0.003) & (0.003) & (0.003) \\
\hline \multirow[t]{2}{*}{ DPMA } & & -0.045 & -0.041 & -0.041 & -0.044 \\
\hline & & $(0.034)$ & $(0.034)$ & $(0.034)$ & $(0.034)$ \\
\hline \multirow[t]{2}{*}{ DGOV } & & 0.043 & 0.045 & 0.042 & 0.041 \\
\hline & & $(0.053)$ & $(0.053)$ & $(0.053)$ & $(0.053)$ \\
\hline \multirow[t]{2}{*}{ DT } & & $-0.581^{* * *}$ & $-0.580^{* * *}$ & $-0.572^{* * *}$ & $-0.580^{* * *}$ \\
\hline & & $(0.132)$ & $(0.132)$ & $(0.132)$ & $(0.132)$ \\
\hline \multirow[t]{2}{*}{ firm_share } & & $0.364^{* * *}$ & $0.362^{* * *}$ & $0.363^{* * *}$ & $0.364^{* * *}$ \\
\hline & & (0.009) & $(0.009)$ & $(0.009)$ & (0.009) \\
\hline \multirow[t]{2}{*}{ _cons } & $10.761^{* * *}$ & $11.682^{* * *}$ & $11.975^{* * *}$ & $11.645^{* * *}$ & $11.668^{* * *}$ \\
\hline & $(0.073)$ & $(0.186)$ & $(0.399)$ & $(0.203)$ & $(0.186)$ \\
\hline $\mathrm{N}$ & 91662 & 91662 & 91662 & 91662 & 91662 \\
\hline $\mathrm{R}^{2}$ & 0.062 & 0.098 & 0.105 & 0.100 & 0.099 \\
\hline $\mathrm{F}$ & 133.741 & 191.555 & 41.266 & 130.014 & 172.034 \\
\hline $\mathrm{P}$ & 0.000 & 0.000 & 0.000 & 0.000 & 0.000 \\
\hline Industry_FE & YES & YES & YES & YES & YES \\
\hline Year_FE & YES & YES & YES & YES & YES \\
\hline Province ${ }^{*}$ Time Trend & NO & NO & YES & NO & NO \\
\hline Island*Time Trend & NO & NO & NO & YES & NO \\
\hline Java-Non Java*Time Trend & NO & NO & NO & NO & YES \\
\hline
\end{tabular}

Note: Standard errors in parentheses; ${ }^{*}$ Significant at $1 \% ;{ }^{* *}$ Significant at $5 \%$; ${ }^{* *}$ Significant at $10 \%$. Source: Authors processed 
Meanwhile, diversification does not significantly affect productivity for firms not located in the industrial area. There is no significant effect of specialization on firm productivity both outside and inside the specialization's industrial area. The three indicators of local industry structure are competition index in the region that does have consistent effect for both firms within and outside the industrial area. The three regressions in columns (3), (4), and (5) Table 3 give consistent results, an improved estimation in comparison to estimation results of column (1) that only include the variable of interest. When controlled with specific trends in each region, the effect of specialization and diversification on firms in industrial estates becomes significantly different from firms outside industrial estates. The effect of specialization is significantly different at the $10 \%$ level. While the effect of diversification is statistically significant at the $10 \%$ level when controlled at the provincial level, $1 \%$ at the island level, and $5 \%$ at the Java and Outer Java levels. With different results between column (2) and column (3), (4) and (5) regression shows that the regression results in column (2) are not yet robust, and there are specific trends at the provincial or island level that affect the impact of specialization and diversification firms in industrial estates are significantly different from those outside the region.

The estimation results with this fixed effect show that there is an influence of local industrial structure on firm productivity, and there are differences in the impact between firms in the industrial area and outside the industrial area. From the column models (3), (4), and (5) in Table 3, the value of $\mathrm{R}^{2}$ is not much different, but the column model (5) gives a more excellent $\mathrm{F}$ value, so that model (5) is better in explaining the influence of local industry structure on productivity. A comparison of the magnitude of its influence on firms inside and outside the industrial estate is summarized in Table 4.

Table 4. Comparison of the magnitude of local industry structure on firms inside and outside the industrial estate

\begin{tabular}{|c|c|c|c|}
\hline Variable & Outside IE & Difference with IE & Inside IE \\
\hline $\begin{array}{l}\text { Average productivity } \\
\text { (InTFP) }\end{array}$ & $\begin{array}{c}11.668 \\
\text { (significant at 1\%) }\end{array}$ & $\begin{array}{l}-0.855 \\
\text { (not significant) }\end{array}$ & $\begin{array}{c}10.813 \\
\text { (not significantly different with } \\
\text { outside IE) }\end{array}$ \\
\hline Specialization (z_LQ) & $\begin{array}{c}-0.037 \\
\text { (significant at 5\%) }\end{array}$ & $\begin{array}{c}-0.249 \\
\text { (significant at } 10 \%)\end{array}$ & -0.286 \\
\hline Diversification (z_Div) & $\begin{array}{l}-0.023 \\
\text { (not significant) }\end{array}$ & $\begin{array}{c}0.108 \\
\text { (significant at 5\%) }\end{array}$ & 0.085 \\
\hline Competition (z_Comp) & $\begin{array}{c}0.012 \\
\text { (significant at 1\%) }\end{array}$ & $\begin{array}{c}-0.006 \\
\text { (not significant) }\end{array}$ & $\begin{array}{c}0.006 \\
\text { (not significantly different with } \\
\text { outside IE) }\end{array}$ \\
\hline
\end{tabular}

Source: Authors calculation

Table 4 shows that although the average productivity within an industrial estate is not significantly different from a firm outside an industrial estate, the effect of the structure 
of the local industry is significantly different under certain conditions. Specialization hurts firm productivity inside and outside the industrial estate. Increasing specialization by one standard deviation, decreasing firm productivity outside the industrial estate by $3.7 \%$, and decreasing firm productivity inside the industrial estate by $28.6 \%$.

Diversity externalities has different effects on firm productivity inside and outside the industrial area. For firms outside the industrial estate, diversification does not affect firm productivity. As for firms in industrial areas, diversification has a positive effect on increasing productivity. Increasing diversification by one standard deviation will increase firm productivity in the industrial area by $8.5 \%$. The effect of diversification is more substantial and more favorable for firms in this industrial area in line with the results of Caragliu et al. (2016) and Marrocu et al. (2013) for the case in European countries that the effect of diversification is more favorable in dense regions, such as areas within industrial estates that show more urban situations. The effect of competition on firms in the industrial area has not been significantly different from firms outside the industrial area. Increasing competition by one standard deviation will increase firm productivity by $1.2 \%$. This is consistent with Porter's theory that competition in similar industries will increase firm productivity compared to a monopoly environment. The positive effect of the competition is also in line with Badr et al. (2019), Khoirunurrofik (2018), Cieślik et al. (2017), Wixe (2015), and Widodo et al. (2014).

There is a difference in the type of local industry structure that affects firm productivity, which is between firms inside and outside the industrial area. Comparing the local industry structure's total impact on firms inside and outside the industrial area, firms in the industrial area benefit the most from the diversification externalities. Meanwhile, firms outside the industrial area only benefit from the externality of the competition. Furthermore, based on the average value of the diversification index in Table 2, firms located in the industrial area are more diverse, and in that context, the externality of diversification increases firm productivity. Unlike the case with firms outside the industrial estates based on the average value of the diversification index in Table 2, the firms' diversity is lower, and thus diversity externalities from other sectors (Jacobs' externalities) do not significantly influence firm productivity.

Table 5. The proportion of Firms by Location and Category of Specialization

\begin{tabular}{clrrrrrr}
\hline Location & \multicolumn{1}{c}{ Category } & 2010 & 2011 & 2012 & 2013 & 2014 & 2015 \\
\hline Outside IE & Non-Specialized Firm* & $30.44 \%$ & $29.55 \%$ & $29.66 \%$ & $29.26 \%$ & $28.89 \%$ & $27.29 \%$ \\
& Specialized Firm ${ }^{* *}$ & $62.19 \%$ & $63.05 \%$ & $62.81 \%$ & $61.28 \%$ & $61.69 \%$ & $63.45 \%$ \\
\multirow{2}{*}{ Inside IE } & Non-Specialized Firm* & $1.94 \%$ & $1.97 \%$ & $2.04 \%$ & $2.68 \%$ & $2.58 \%$ & $2.34 \%$ \\
& Specialized Firm ${ }^{* *}$ & $5.42 \%$ & $5.43 \%$ & $5.49 \%$ & $6.77 \%$ & $6.83 \%$ & $6.92 \%$ \\
\hline
\end{tabular}

Note: *Non-Specialized Firm is a firm that operates in a type of industry that is not a district/city specialization sector, namely an industry with an LQ index value of less than or equal to $1 .{ }^{* *}$ Specialized Firm, which is a firm that operates in a type of regency/city specialization industry, namely industries with LQ index values above 1.

Source: Calculated from SI data 
Based on MAR theory, the externality of specialization should have a positive effect on productivity. However, the results of the estimation did not match what was expected. The specialization effect is also harmful to firms outside the industrial area, although nationally, firms outside the industrial area have, on average higher specialization index. The negative effect of this specialization is in line with the results of Combes (2000) research for studies in France, Batisse (2002) in China, Marrocu et al. (2013) for old countries in Europe, and Zhang (2017) for the manufacturing industry in China. According to Marrocu et al. (2013), the influence of harmful specialization can occur because agglomeration's economic factors are more significant. For example, congestion and competition between firms and similar industries cause additional costs for the firm (Marrocu et al., 2013). As shown in Table 5, firms operating in the type of industry, which are specialized sectors of the district/city (specialized firm), are mostly located outside the industrial area, amounting to around $60 \%$. Besides, firms outside the industrial estate are mostly small firms, and their productivity is lower. If competition in a similar industry is robust, small firms tend to lose competitiveness and productivity decline.

Detail analysis on firms inside industrial estates, we explore what type of local industry structures affect firms' productivity inside the industrial estate. The influence of local industrial structures on firms in industrial estates (Inside IE in Table 4) shows that specialization, namely a group of firms with similar industries in industrial areas, harms firm productivity. This means that agglomeration of similar industries that provide MAR externality, through the labor pool, sharing intermediate input, and knowledge spillover does not occur in industrial estates. The study of Aritenang and Chandramidi (2020) stated that the primary motivation for firms located in industrial estates is not to obtain agglomeration economies from similar industries but for pragmatic reasons such as land availability and infrastructure (electricity, water, easy transportation) and security in industrial estates. Besides, specific industrial sectors that dominate an industrial area (specialization) are characterized by a protectionist view of knowledge and information for fear that sharing information can make them lose their competitiveness (Aritenang \& Chandramidi, 2020). Meanwhile, diversification has a positive effect on firm productivity in industrial estates. This suggests that Jacobs' externality, which increases productivity through cross-industry knowledge spillover, is possible in industrial estates. Companies in industrial estates work together with complementarity in their value chains (Aritenang \& Chandramidi, 2020). This pattern of cooperation will encourage cross-industry knowledge spillover and increase firm productivity.

For robustness checks, a regression is carried out on firm sub-samples based on locations inside and outside the industrial area, with the results shown in Table 6. Columns (1), (3), and (5) in Table 6 are the estimation results for a sub-sample of firms located within the industrial area, where added control of fixed effects is specific to the island level in column (3) and at the Java level Outside Java in column (5) interacted with time trend. While columns (2), (4), and (6) are the estimation results 
for a sub-sample of firms located outside the industrial area, where added control of fixed effects are specific to the island level in column (4), and at the level of the Outer Java islands Java in column $(6$,$) interacted with time trend. In general, both for firms$ in the industrial area and for firms outside the industrial area, the estimation results are consistent with the previous regression results summarized in Table 4, but with a different level of significance.

Table 6. Estimation Results Sub Sample (Fixed Effect)

\begin{tabular}{|c|c|c|c|c|c|c|}
\hline Dependent: & (1) & (2) & (3) & (4) & (5) & (6) \\
\hline LnTFP & IE & Non IE & IE & Non IE & IE & Non IE \\
\hline \multirow[t]{2}{*}{$\mathrm{z}_{-} \mathrm{LQ}$} & $-0.488^{* * *}$ & $-0.030^{*}$ & $-0.433^{* *}$ & $-0.034^{* *}$ & $-0.472^{* * *}$ & $-0.034^{* *}$ \\
\hline & $(0.176)$ & $(0.016)$ & (0.178) & $(0.016)$ & $(0.177)$ & $(0.016)$ \\
\hline \multirow[t]{2}{*}{ z_Div } & $0.100^{* *}$ & $-0.024^{*}$ & 0.069 & $-0.025^{*}$ & 0.066 & $-0.025^{*}$ \\
\hline & $(0.050)$ & (0.014) & $(0.054)$ & $(0.014)$ & $(0.054)$ & $(0.014)$ \\
\hline \multirow[t]{2}{*}{ z_Comp } & 0.000 & $0.011^{\cdots *}$ & 0.001 & $0.012^{* * *}$ & 0.001 & $0.013^{* * *}$ \\
\hline & $(0.018)$ & $(0.003)$ & (0.018) & $(0.003)$ & (0.018) & $(0.003)$ \\
\hline \multirow[t]{2}{*}{ InFirm_labor } & 0.023 & $0.117^{* * * *}$ & 0.020 & $0.119^{* * *}$ & 0.021 & $0.117^{* * *}$ \\
\hline & $(0.029)$ & $(0.009)$ & (0.030) & $(0.009)$ & $(0.029)$ & $(0.009)$ \\
\hline \multirow[t]{2}{*}{ LnKLratio } & $-0.095^{* * *}$ & $-0.075^{* * *}$ & $-0.097^{* * *}$ & $-0.075^{* * *}$ & $-0.095^{* * *}$ & $-0.076^{* * *}$ \\
\hline & (0.012) & $(0.003)$ & (0.012) & (0.003) & (0.012) & (0.003) \\
\hline \multirow[t]{2}{*}{ DPMA } & -0.055 & -0.042 & -0.053 & -0.036 & -0.057 & -0.040 \\
\hline & (0.090) & $(0.036)$ & (0.090) & $(0.036)$ & (0.090) & $(0.036)$ \\
\hline \multirow[t]{2}{*}{ DGOV } & $-0.596^{* *}$ & 0.081 & $-0.587^{* *}$ & 0.078 & $-0.584^{* *}$ & 0.080 \\
\hline & $(0.245)$ & $(0.055)$ & $(0.250)$ & $(0.055)$ & $(0.245)$ & $(0.055)$ \\
\hline \multirow[t]{2}{*}{ DT } & 0.617 & $-0.727^{* * *}$ & 0.580 & $-0.717^{* * *}$ & 0.601 & $-0.727^{* * *}$ \\
\hline & $(0.475)$ & (0.138) & $(0.476)$ & (0.138) & $(0.476)$ & (0.138) \\
\hline \multirow[t]{2}{*}{ firm_share } & $0.350^{* * *}$ & $0.369^{* * *}$ & $0.348^{* * *}$ & $0.368^{* * *}$ & $0.348^{* * *}$ & $0.369^{* * *}$ \\
\hline & $(0.020)$ & $(0.010)$ & $(0.020)$ & (0.010) & $(0.020)$ & $(0.010)$ \\
\hline \multirow[t]{2}{*}{ _cons } & $11.834^{* * *}$ & $11.675^{* * *}$ & $12.006^{* * *}$ & $11.660^{* * *}$ & $11.917^{* * *}$ & $11.670^{* * *}$ \\
\hline & $(0.766)$ & $(0.189)$ & $(0.770)$ & $(0.205)$ & $(0.768)$ & (0.188) \\
\hline $\mathrm{N}$ & 5260 & 86402 & 5260 & 86402 & 5260 & 86402 \\
\hline r2 & 0.130 & 0.097 & 0.134 & 0.099 & 0.131 & 0.098 \\
\hline$F$ & 16.830 & 198.404 & 12.261 & 130.213 & 14.940 & 176.467 \\
\hline$P$ & 0.000 & 0.000 & 0.000 & 0.000 & 0.000 & 0.000 \\
\hline Industry_FE & YES & YES & YES & YES & YES & YES \\
\hline Year_FE & YES & YES & YES & YES & YES & YES \\
\hline Island*Time Trend & NO & NO & YES & YES & NO & NO \\
\hline Java-Non Java*Time Trend & NO & NO & NO & NO & YES & YES \\
\hline
\end{tabular}

Note: Standard errors in parentheses; ${ }^{*}$ Significant at $1 \% ;{ }^{* *}$ Significant at $5 \%$; ${ }^{* *}$ Significant at $10 \%$.

Source: Authors processed 
The specialization effect is significantly negative on firm productivity inside and outside the industrial area, with a more negative value for firms in the industrial area. Meanwhile, the effect of diversification is different for firms inside and outside the industrial area. For firms in the industrial area, diversification is positive on firm productivity, but the effect is significant only in column (1). When controlled by region-specific effects at the island level that are interacted with time trends in columns (3) and (5), the effect of diversification on firm productivity in an industrial area is positive but not significant. The reduced significance of diversification on firms in this industrial area may be due to the smaller number of sub-samples when controlled by observations grouped by island group and year. As for firms outside the industrial area, diversification is negative and significant at the $10 \%$ level. For the competition, the effect is positive but not significant on firm productivity in the industrial area. As for firms outside the industrial estate, competition is positive and significantly increases firm productivity.

For robustness checks, estimations are also conducted using balanced panel data from 2010-2015 and are controlled by firm age, with firm observations included in the SI survey in 2006. This is done to determine whether the influence of specialization and diversification on firm productivity is also affected by the industry's maturity. Duranton \& Puga (2001), with their "nursery cities" concept, state that mature industries will be more productive in specialized areas while young industries and small firms will be important in diversified areas. Estimation results with fixed effects on the balance panel data can be seen in appendix 1 for the entire sample and appendix 2 for sub-samples based on location inside and outside the industrial area.

For both the overall sample and sub-sample, the estimation results are consistent with the estimation results from the unbalance panel in Table 4. Specialization has a negative and significant effect on firm productivity inside and outside the industrial area, with a more significant decrease in firms' productivity in the industrial area. The effect of diversification is positive for firm productivity in industrial estates and negatively for firms outside the industrial area. While competition has a positive effect on firm productivity outside the industrial estate, its effect on the industrial area is not significant. The findings of consistent estimation results in Table 4 show that the influence of local industry structures on firms' productivity inside and outside industrial estates and the magnitude of the influence is robust.

\section{Conclusion}

This study aims to determine the effect of local industry structure on firm productivity in the industrial area. By using unbalanced panel data, this result shows that there is an effect of local industry structure on firm productivity, and the effect is different on the firm in the industrial area. Specialization decreases both firms' productivity in an industrial area and outside industrial area, with a more significant reduction in productivity for firms in industrial estates. Diversification also gives a 
different effect. For firms in the industrial area, diversification has a positive effect on increasing firm productivity. As for firms outside the region, diversification has a negative effect on firm productivity though the effect is less significant. In regard to competition indicator, there is a positive and significant effect of competition on firm productivity outside the region. However, the effect is not significant for firms' productivity in the industrial area.

From our empirical results, firms in the industrial area benefit from a diversified local industry structure. As the government requires large firms in an industry to be located in an industrial area, the government and the estate management need to arrange new firms' location regarding the industrial area aligning to a favorable environment for increasing productivity. Because the firms' presence in the industrial area alone empirically has not make the productivity of firms in the area higher than firms outside the industrial area. The government needs to make policies that can increase firm productivity in the industrial area by structuring its industrial structure.

\section{References}

Antonietti, R., \& Cainelli, G. (2011). Spatial Agglomeration in a Structural Model of Innovation, Productivity, and Export is a Firm-Level Analysis. The Annals of Regional Science, 46(3), 577-600. https://doi.org/10.1007/s00168-009-0359-7

Aritenang, A. F., \& Chandramidi, A. N. (2020). The Impact of Special Economic Zones and Government Intervention on Firm Productivity: The Case of Batam, Indonesia. Bulletin of Indonesian Economic Studies, 56(2), 225-249.

Badr, K., Rizk, R., \& Zaki, C. (2019). Firm Productivity and Agglomeration Economies: Evidence from Egyptian Data. Applied Economics, 51(51), 5528-5544.

Batisse, C. (2002). Dynamic Externalities and Local Growth: A Panel Data Analysis Applied to Chinese Provinces. China Economic Review, 13(2-3), 231-251.

Beaudry, C., \& Schiffauerova, A. (2009). Who is Right, Marshall or Jacobs? The Localization Versus Urbanization Debate. Research Policy, 38(2), 318-337.

Becattini, G. (1990). The Marshallian Industrial District as a Socio-Economic Notion. Revue D'Economie Industrielle, 157, 13-32.

Boschma, R. A., \& Lambooy, J. G. (2002). Knowledge, Market Structure, and Economic Coordination: Dynamics of Industrial Districts. Growth and Change, 33(3), 291-312.

Boschma, R. A., \& Ter Wal, A. L. J. (2007). Knowledge Networks and Innovative Performance in an Industrial District: The Case of a Footwear District in the South of Italy. Industry and Innovation, 14(2), 177-199.

Cainelli, G. (2008). Spatial Agglomeration, Technological Innovations, and Firm Productivity: Evidence from Italian Industrial Districts. Growth and Change, 39(3), 414-435. https://doi.org/10.1111/j.1468-2257.2008.00432.x 
Caragliu, A., de Dominicis, L., \& de Groot, H. L. (2016). Both Marshall and Jacobs were right! Economic geography, 92(1), 87-111.

Cheng, Z., \& Jin, W. (2020). Agglomeration Economy and the Growth of Green Total-Factor Productivity in Chinese Industry. Socio-Economic Planning Sciences, 101003.

Cieślik, A., Gauger, I., \& Michaek, J. J. (2017). Agglomeration Externalities, Competition, and Productivity: Empirical Evidence from Ukraine firms. The Annals of Regional Science, 60(1), 213-233. https://doi.org/10.1007/s00168-017-0851-4

Combes, P. (2000). Economic structure and local growth: France, 1984-1993. Journal of urban economics, 47(3), 329-355. https://doi.org/10.1006/juec.1999.2143

Duranton, G., \& Puga, D. (2001). Nursery Cities: Urban Diversity, Process Innovation, and the Life Cycle of Products. American Economic Review, 91(5), 1454-1477.

Fafchamps, M., \& El Hamine, S. (2017). Firm Productivity, Wages, and Agglomeration Externalities. Research in Economics, 71(2), 291-305.

Fan, C. C., \& Scott, A. J. (2003). Industrial Agglomeration and Development: a Survey of Spatial Economic Issues in East Asia and a Statistical Analysis of Chinese Regions. Economic geography, 79(3), 295-319.

Galliano, D., Magrini, M.-B., \& Triboulet, P. (2015). Marshall's versus Jacobs' Externalities in Firm Innovation Performance: The Case of French Industry. Regional Studies, 49(11), 1840-1858. https://doi.org/10.1080/00343404.2014.950561

Gill, I. S., \& Goh, C.-C. (2010). Scale Economies and Cities. The World Bank Research Observer, 25(2), 235-262. https://doi.org/10.1093/wbro/lkp022

Glaeser, E. L (Ed). (2010). Agglomeration Economics. Chicago: University of Chicago Press.

Glaeser, E. L., Kallal, H. D., Scheinkman, J. A., \& Shleifer, A. (1992). Growth in Cities. Journal of Political Economy, 100(6), 1126-1152. https://doi.org/10.1086/261856

Gordon, I. R., \& McCann, P. (2000). Industrial Clusters: Complexes, Agglomeration, and/or Social Networks? Urban Studies, 37(3), 513-532.

Iammarino, S., \& McCann, P. (2006). The Structure and Evolution of Industrial Clusters: Transactions, Technology, and Knowledge Spillovers. Research Policy, 35(7), 10181036. https://doi.org/10.1016/j.respol.2006.05.004

Khoirunurrofik. (2018). Local Economic Structure, Productivity Growth, and Industry Life Cycle: Evidence from Indonesia. Asia-Pacific Journal of Regional Science, 2(2), 453-475.

Knoben, J., Arikan, A., van Oort, F., \& Raspe, O. (2016). Agglomeration and Firm Performance: One Firm's Medicine is Another Firm's Poison. Environment and Planning A: Economy and Space, 48(1), 132-153.

Kuncoro, A. (2009). Spatial Agglomeration, Firm Productivity, and Government Policies 
in Indonesia: Concentration and Deconcentration in the Manufacturing Sector. In Huang, Y., \& Bocchi, A. M. (Eds). Reshaping Economic Geography in East Asia, 156-168. Washington DC: The World Bank.

Levinsohn, J., \& Petrin, A. (2003). Estimating Production Functions Using Inputs to Control for Unobservables. The Review of Economic Studies, 70(2), 317-341.

Li, D., Lu, Y., \& Wu, M. (2012). Industrial Agglomeration and Firm Size: Evidence from China. Regional Science and Urban Economics, 42(1-2), 135-143.

Malmberg, A., Malmberg, B., \& Lundequist, P. (2000). Agglomeration and Firm Performance: Economies of Scale, Localization, and Urbanization Among Swedish Export Firms. Environment and Planning, 32(2), 305-321.

Marrocu, E., Paci, R., \& Usai, S. (2013). Productivity growth in the old and new Europe: the role of agglomeration externalities. Journal of Regional Science, 53(3), 418-442.

Rigby, D. L., \& Brown, W. M. (2015). Who Benefits from Agglomeration? Regional Studies, 49(1), 28-43. https://doi.org/10.1080/00343404.2012.753141.

Sabri, M., D Nachrowi, N., Soetjipto, W., \& Panennungi, M. A. (2018). Industrial Estate and Export Decision of Manufacturing Firms in Indonesia. Malaysian Journal of Economic Studies, 55(2), 189-207. https://doi.org/10.22452/MJES. vol55no2.3.

Suharyani, S., \& Mahi, B. R. (2018). Aglomerasi dan Perbedaan Produktivitas Perusahaan di Dalam dan di Luar Kawasan Berikat. Jurnal Ilmu Ekonomi dan Pembangunan, 18(2), 111-128. https://doi.org/10.20961/jiep.v18i2.24970

Van der Panne, G. (2004). Agglomeration Externalities: Marshall versus Jacobs. Journal of Evolutionary Economics, 14(5), 593-604. https://doi.org/10.1007/s00191-0040232-x.

Van Oort, F. (2015). Unity in the Variety? Agglomeration Economics Beyond the Specialization-Diversity Controversy. In. Karlsson, C., Anderson, M., \& Norman, $\mathrm{T}$ (Eds). Handbook of Research Methods and Applications in Economic Geography, 259-271.

Wardani, K., \& Yudhistira, M. H. (2020). Konsentrasi Spasial, Aglomerasi dan Produktivitas Perusahaan Industri Manufaktur Indonesia. Jurnal Manajemen Industri dan Logistik, 4(2), 146-156. https://doi.org/10.30988/jmil.v4i2.544

Widodo, W., Salim, R., \& Bloch, H. (2014). Agglomeration Economies and Productivity Growth in Manufacturing Industry: Empirical Evidence from Indonesia. Economic Record, 90, 41-58. https://doi.org/10.1111/1475-4932.12115

Winardi, W., Priyarsono, D. S., Siregar, H., \& Kustanto, H. (2017). Kinerja Sektor Industri Manufaktur Provinsi Jawa Barat Berdasarkan Lokasi di dalam dan di Luar Kawasan Industri. Journal of Technology Management, 16(3), 241-257. 
Wixe, S. (2015). The Impact of Spatial Externalities: Skills, Education, and Plant Productivity. Regional Studies, 49(12), 2053-2069.

Zhang, Y. (2017). An Empirical Study on Externality and Total Factor Productivity of Manufacturing Industry in China. Open Journal of Social Sciences, 5(03), 269. 


\section{Appendix 1.}

Estimation Results Overall Sample with Balanced Data Panel (Fixed Effect)

\begin{tabular}{|c|c|c|c|c|c|}
\hline Dependent: & (1) & $(2)$ & (3) & (4) & (5) \\
\hline Ln TFP & FE & $\mathrm{FE}$ & FE & $\mathrm{FE}$ & $\mathrm{FE}$ \\
\hline \multirow[t]{2}{*}{$z_{-}$LQ } & -0.025 & $-0.041^{* *}$ & $-0.045^{* *}$ & $-0.042^{* *}$ & $-0.044^{* *}$ \\
\hline & $(0.020)$ & (0.019) & (0.019) & (0.019) & (0.019) \\
\hline \multirow[t]{2}{*}{ z_Div } & -0.023 & -0.024 & -0.025 & $-0.026^{*}$ & $-0.026^{*}$ \\
\hline & $(0.016)$ & (0.015) & (0.016) & $(0.015)$ & (0.015) \\
\hline \multirow[t]{2}{*}{ z_Comp } & $0.012^{* * *}$ & $0.011^{* * *}$ & $0.012^{* * *}$ & $0.012^{* * *}$ & $0.013^{* * *}$ \\
\hline & (0.003) & (0.003) & (0.003) & $(0.003)$ & (0.003) \\
\hline \multirow[t]{2}{*}{ D_KI } & -0.775 & -0.935 & -0.801 & -0.816 & -0.849 \\
\hline & (0.704) & (0.689) & $(0.688)$ & (0.689) & (0.689) \\
\hline \multirow[t]{2}{*}{ zLQ_KI } & -0.196 & -0.263 & $-0.299^{*}$ & $-0.298^{*}$ & $-0.277^{*}$ \\
\hline & $(0.165)$ & $(0.162)$ & $(0.162)$ & $(0.162)$ & (0.162) \\
\hline \multirow[t]{2}{*}{ zDiv_KI } & $0.114^{* *}$ & $0.094^{*}$ & $0.097^{*}$ & $0.145^{* * *}$ & $0.133^{* * *}$ \\
\hline & $(0.051)$ & $(0.050)$ & $(0.054)$ & $(0.051)$ & $(0.050)$ \\
\hline \multirow[t]{2}{*}{ zComp_KI } & -0.011 & -0.003 & -0.004 & -0.002 & -0.004 \\
\hline & $(0.024)$ & (0.023) & $(0.023)$ & $(0.023)$ & $(0.023)$ \\
\hline \multirow[t]{2}{*}{ InFirm_labor } & & $0.093^{* * *}$ & $0.094^{* * *}$ & $0.094^{* * *}$ & $0.093^{* * *}$ \\
\hline & & (0.010) & (0.010) & (0.010) & (0.010) \\
\hline \multirow[t]{2}{*}{ InKLratio } & & $-0.082^{* * *}$ & $-0.081^{* * *}$ & $-0.082^{* * *}$ & $-0.082^{* *}$ \\
\hline & & $(0.004)$ & $(0.004)$ & (0.004) & (0.004) \\
\hline \multirow[t]{2}{*}{ DPMA } & & -0.026 & -0.019 & -0.022 & -0.024 \\
\hline & & $(0.037)$ & $(0.037)$ & $(0.037)$ & (0.037) \\
\hline \multirow[t]{2}{*}{ DGOV } & & 0.025 & 0.020 & 0.025 & 0.026 \\
\hline & & (0.057) & $(0.057)$ & $(0.057)$ & (0.057) \\
\hline \multirow[t]{2}{*}{ DT } & & $-0.532^{* * *}$ & $-0.547^{* * *}$ & $-0.524^{* * *}$ & $-0.532^{* *}$ \\
\hline & & $(0.145)$ & $(0.145)$ & $(0.145)$ & $(0.145)$ \\
\hline \multirow[t]{2}{*}{ firm_share } & & $0.333^{* * *}$ & $0.332^{* * *}$ & $0.332^{* * *}$ & $0.333^{* * *}$ \\
\hline & & (0.009) & (0.009) & (0.009) & (0.009) \\
\hline \multirow[t]{2}{*}{ Firm Age } & & $0.107^{* * *}$ & -0.046 & $0.107^{* * *}$ & $0.112^{\ldots *}$ \\
\hline & & $(0.002)$ & (0.102) & (0.019) & $(0.002)$ \\
\hline \multirow[t]{2}{*}{ _cons } & $10.860^{* * *}$ & $9.825^{* * *}$ & $13.470^{* * *}$ & $9.784^{* * *}$ & $9.713^{* * *}$ \\
\hline & $(0.083)$ & $(0.213)$ & $(2.448)$ & $(0.504)$ & $(0.214)$ \\
\hline $\mathrm{N}$ & 67841 & 67841 & 67841 & 67841 & 67841 \\
\hline $\mathrm{R}^{2}$ & 0.064 & 0.102 & 0.110 & 0.104 & 0.103 \\
\hline $\mathrm{F}$ & 106.659 & 155.210 & 33.754 & 105.609 & 139.532 \\
\hline$P$ & 0.000 & 0.000 & 0.000 & 0.000 & 0.000 \\
\hline Industry_FE & YES & YES & YES & YES & YES \\
\hline Year_FE & YES & YES & YES & YES & YES \\
\hline Province* Time Trend & NO & NO & YES & NO & NO \\
\hline Island*Time Trend & NO & NO & $\mathrm{NO}$ & YES & NO \\
\hline Java-Non Java*Time Trend & NO & NO & NO & NO & YES \\
\hline
\end{tabular}

Note: Standard errors in parentheses; ${ }^{*}$ Significant at $1 \% ;{ }^{* *}$ Significant at $5 \%$; ${ }^{* *}$ Significant at $10 \%$. Source: Authors processed 


\section{Appendix 2.}

Estimation Result on Sub Sample with Balanced Data Panel (Fixed Effect)

\begin{tabular}{|c|c|c|c|c|c|c|}
\hline Dependent: & (1) & (2) & (3) & (4) & (5) & (6) \\
\hline Ln TFP & IE & Non IE & IE & Non IE & IE & Non IE \\
\hline \multirow[t]{2}{*}{ z_LQ } & $-0.459^{* *}$ & $-0.035^{*}$ & $-0.456^{* *}$ & $-0.038^{*}$ & $-0.438^{* *}$ & $-0.039^{* *}$ \\
\hline & (0.190) & (0.019) & (0.191) & (0.019) & (0.191) & (0.019) \\
\hline \multirow[t]{2}{*}{ z_Div } & $0.119^{* *}$ & $-0.026^{*}$ & 0.083 & $-0.029^{*}$ & 0.078 & $-0.028^{*}$ \\
\hline & $(0.054)$ & $(0.015)$ & (0.059) & (0.015) & (0.058) & $(0.015)$ \\
\hline \multirow[t]{2}{*}{ z_Comp } & 0.019 & $0.012^{* * *}$ & 0.020 & $0.013^{* * *}$ & 0.022 & $0.014^{* * *}$ \\
\hline & $(0.027)$ & $(0.003)$ & $(0.027)$ & (0.003) & $(0.027)$ & (0.003) \\
\hline \multirow[t]{2}{*}{ InFirm_labor } & 0.025 & $0.101^{* * *}$ & 0.026 & $0.102^{* * *}$ & 0.023 & $0.101^{* * *}$ \\
\hline & $(0.031)$ & $(0.010)$ & $(0.031)$ & (0.010) & $(0.031)$ & (0.010) \\
\hline \multirow[t]{2}{*}{ InKLratio } & $-0.100^{* * *}$ & $-0.080^{* * *}$ & $-0.097^{* * *}$ & $-0.080^{* * *}$ & $-0.100^{* * *}$ & $-0.080^{* * *}$ \\
\hline & (0.013) & $(0.004)$ & $(0.013)$ & $(0.004)$ & $(0.013)$ & $(0.004)$ \\
\hline \multirow[t]{2}{*}{ DPMA } & 0.091 & -0.048 & 0.082 & -0.043 & 0.084 & -0.046 \\
\hline & $(0.097)$ & $(0.041)$ & $(0.097)$ & $(0.041)$ & $(0.097)$ & $(0.041)$ \\
\hline \multirow[t]{2}{*}{ DGOV } & $-0.644^{* *}$ & 0.068 & $-0.531^{* *}$ & 0.063 & $-0.631^{* *}$ & 0.068 \\
\hline & $(0.256)$ & $(0.058)$ & $(0.266)$ & $(0.058)$ & $(0.256)$ & $(0.058)$ \\
\hline \multirow[t]{2}{*}{ DT } & 0.445 & $-0.660^{* * *}$ & 0.453 & $-0.653^{* * *}$ & 0.430 & $-0.662^{* * *}$ \\
\hline & $(0.521)$ & $(0.152)$ & (0.521) & $(0.152)$ & $(0.521)$ & $(0.152)$ \\
\hline \multirow[t]{2}{*}{ firm_share } & $0.333^{* * *}$ & $0.333^{* * *}$ & $0.328^{* * *}$ & $0.332^{* * *}$ & $0.332^{* * *}$ & $0.333^{* * *}$ \\
\hline & $(0.020)$ & (0.010) & $(0.020)$ & $(0.010)$ & $(0.020)$ & (0.010) \\
\hline \multirow[t]{2}{*}{ Firm Age } & $0.079^{* * *}$ & $0.109^{* * *}$ & $0.069^{* * *}$ & $0.107^{* * *}$ & $0.069^{* * *}$ & $0.115^{* * *}$ \\
\hline & (0.009) & $(0.002)$ & (0.011) & (0.019) & $(0.011)$ & $(0.002)$ \\
\hline \multirow[t]{2}{*}{ _cons } & $10.904^{* * *}$ & $9.718^{* * *}$ & $11.110^{* * *}$ & $9.735^{* * *}$ & $11.140^{* * *}$ & $9.602^{* * *}$ \\
\hline & $(0.857)$ & $(0.216)$ & $(0.869)$ & $(0.508)$ & $(0.864)$ & $(0.217)$ \\
\hline $\mathrm{N}$ & 4346 & 63495 & 4346 & 63495 & 4346 & 63495 \\
\hline $\mathrm{R}^{2}$ & 0.141 & 0.101 & 0.148 & 0.103 & 0.143 & 0.102 \\
\hline $\mathrm{F}$ & 15.601 & 158.834 & 11.542 & 104.418 & 13.903 & 141.520 \\
\hline$P$ & 0.000 & 0.000 & 0.000 & 0.000 & 0.000 & 0.000 \\
\hline Industry_FE & YES & YES & YES & YES & YES & YES \\
\hline Year_FE & YES & YES & YES & YES & YES & YES \\
\hline Island*Time Trend & NO & NO & YES & YES & NO & NO \\
\hline Java-Non Java*Time Trend & NO & NO & NO & NO & YES & YES \\
\hline
\end{tabular}

Note: Standard errors in parentheses; ${ }^{*}$ Significant at $1 \%$; ${ }^{* *}$ Significant at $5 \%$; ${ }^{* *}$ Significant at $10 \%$.

Source: Authors processed 